\title{
A Narrative Inquiry into EFL Teachers' Professional Experiences in Blended Learning during COVID-19 Pandemic
}

\author{
Ika Meilinda Ummul Ma'rufa* and Mutmainnah Mustofa \\ Universitas Islam Malang, Indonesia
}

\begin{abstract}
Extensive studies have been geared to exploring the implementation of blended learning in the education domain. However, there is a paucity of research that examines such implementation from teachers' perspectives. To fill this gap, the present study investigates the lived experiences of EFL teachers in enacting blended learning during the COVID-19 pandemic. To capture the teachers' stories, a narrative inquiry was employed. Data were garnered through the narrative frame, narrative box, and interview guide. Findings suggest that the teachers applied different online platforms to teach English in blended learning, then the school centralized to use Google classroom as the main platform in the online class. Furthermore, the lesson, scheduling, Internet connection, and students' self-regulated learning awareness complicated the implementation of blended learning during the COVID19 pandemic. The paper suggests policymakers enact online pedagogy based on the actual teacher training and maximise schooling facilities as a learning support.
\end{abstract}

\author{
ARTICLE HISTORY \\ Received 15 April 2021 \\ Accepted 17 June 2021 \\ Published 04 July 2021

\section{KEYWORDS:} \\ blended learning, COVID- \\ 19 pandemic, narrative \\ inquiry, teacher \\ professional development
}

\section{Introduction}

The World Health Organization (WHO) declared coronavirus disease (COVID-19) as a pandemic that has presented a temporary threat to humanity worldwide. The general director of WHO in March 2020 announced COVID-19 as a pandemic after assessing the rapid spread and seriousness of the deadly virus across the globe with the additional announcement of social distancing as a means for restraining the spread of the virus (WHO, 2020). In Indonesia, the number of COVID-19 cases has grown higher time by time. Therefore, the Indonesian government issued some regulations to prevent its spread, including in the education sector. The Indonesian Ministry of Education and Culture has published Circular Letter No. 15, 2020, regarding the guideline for teaching and learning from home during the pandemic. As a result, all educational institutions in Indonesia are required to conduct distance learning, by which it changes traditional teaching system from face to face to be online learning and relies on the use of technology. Consequently, online learning is completely dependent on technological devices and Internet connections (Adedoyin \& Soykan, 2020).

Empirically speaking, some challenges in implementing online learning in developing countries such as Indonesia are the lack of preparation in terms of school readiness, teacher capability in information and communication technology (ICT), the availability of Internet access, and students' selfregulated ability toward the online learning. The dependency of online learning on technological equipment and certain platforms is also another problem for education aspect. The application of online learning from home has presented various problems, including school infrastructure provision (Bakalar, 2018). Meanwhile, the teachers have restricted resources to take part in online learning, and many students do not have any access to internet connections and the necessary electronic devices (Lie, 2020). 
Recently, new normal era has been implemented in Indonesia, and the Ministry of Education and Culture allowed schools for green zones areas to conduct teaching and learning process with certain requirements such as to obey guidelines of the health protocol and to keep the social distancing (Sipres, 2020). Anchored by such situation, the appropriate method that is possible to be implemented is blended learning. Moreover, the concept of blended learning is suitable with the $21^{\text {st }}$-century era, because it relates to technology development. Garrison and Kanuka (2004) define blended learning as "the thoughtful integration of classroom face-to-face learning experiences with online learning experiences" (p. 96). Although the introduction of blended learning in most developing countries faced many challenges, this learning approach is widely considered the most effective one (Kintu et al., 2017). Such a claim is supported by Dziuban et al. (2018), who contends that blended learning provides a successful and effective learning environment. Thus, the combination of technological appliances and the availability of interaction both teachers and students' demand for more effective and efficient teaching and learning processes.

The existence of blended learning recently has enticed many researchers to investigate it. Many empirical studies have been conducted to examine the quality of blended learning from various aspects. A recent study conducted by Barkhuizen and Mandieta (2019) examined how the program of blended learning was implemented in a Colombian tertiary institution. Another study was conducted by Sriwichai (2020) which explored students' readiness for learning English course through blended learning environment and investigate problems and challenges that the students faced in their learning. In addition, Wright (2017) investigated Malaysian undergraduate EFL perception online compared with face to face. Chan (2019) examined pre-service teacher perceptions and the interaction between traditional and constructivist conceptions. In Indonesia, Setyaningsih (2020) conducted a survey to explore students' perspectives on implementing blended learning in the context of higher education. Although extensive research has been carried out on the issue of blended learning, little exploration has been done in examining English as a foreign language (EFL) teachers' professional experiences blended learning during COVID -19 pandemic using a narrative inquiry perspective.

This present research investigates lived experiences of EFL teachers that have taught for more than 20 years. The EFL teacher experience using blended learning during the pandemic was explored deeper through narrative inquiry. This methodology interprets experiences in humans as living organisms that tell the story in their lives. The narrative inquiry also allows researchers to give space to make teachers' personal experiences a professional knowledge and intellectual knowledge for others (Connelly \& Clandinin, 2006). Based on the background of this study, a research question was designed: To what extent do the EFL teachers enact their professional experiences during the implementation of blended learning?

\section{Literature Review Teacher Professional Development}

In Indonesia, teachers' professionalism is based on the national policy, by which teachers' ability to conduct their roles, function, and their behavior at school and society context is regulated by the government. As professional educators, the law of teachers and lectures No.14 year 2005 gives a mandate to the teachers by their primary task such as to educate, teach, guide, direct, train, access, and evaluate students from early childhood education, formal education, primary education, to secondary education. Meanwhile, Indonesian teachers often faced dilemma in carrying out their duties. On the one hand, the teachers have to serve students with appropriate support to learn in the formal education settings. They have to try hard themselves both in capacity as individuals and professionals (Kiilo \& Kutsar, 2012). Teacher professional experience is basically affected by functions, status, quality and teachers' work (Richards \& Schmidt, 2010).

\section{Blended Learning in Education Domain}

Blended learning means integrating the web and face-to-face method to make the effectiveness experience both for teacher and the learner, so blended learning becomes a constructivist approathat features the potential to transfer better education in line with the development of technology. According to Garrison and Vaughan (2008), blended learning integrates thoughtfully selected and complementary face-to-face and online approaches and technologies. Its implementation has been described to be more effective than the classical face-to-face or purely online learning 
instruction (Arifani, Khaja, Suryanti, \& Wardhono, 2019; Kurucova et al., 2018). Blended learning leads the students to be able have learning experiences between individuals and their environment in form of interaction and students can be active in classroom discussion. Learning outcomes can be improved through blended learning and it is the most effective way to support teaching and learning activities (Dziuban et al., 2018).

The quality of learning management system content for learners can predict good performance in e-and blended learning environments and can lead to learner satisfaction. On the whole, poor quality technology yields no satisfaction by users and therefore the quality of technology significantly affects satisfaction (Piccoli, Ahmad, \& Ives, 2001). Continued navigation through a learning management system increases use and is an indicator of success in blended learning (Delone \& McLean, 2003). The efficient use of learning management system and its tools improves learning outcomes in e-learning and blended learning environments. The utilization of technology in EFL teaching and learning leads to an alteration in the roles of teachers and learners and initiates the innovative online teaching atmosphere and strategies such as e-learning, the flipped approach, and blended learning. Current research has indicated that teachers and students learn successfully in online settings (Gillian \& Lew, 2018; Kocoglu et al., 2011). Conversely, it has also been recognized that single-mode online learning courses cannot promote optimum attainment for successful learning (Kocoglu et al. 2011). As a result, several researchers have attempted to combine traditional teaching model face-to-face courses with an online learning system to advocate active and flexible learning (Garnham \& Kaleta, 2002).

\section{Previous Studies: Existing Gaps in the Literature}

Many studies documented that blended learning positively impacts teaching EFL, but some studies also include some problems perceived by the teachers. A study conducted by Nissen and Tea (2012) found that most of the teachers found it difficult in understanding the course design of blended learning. Furthermore, the teachers though that face-to-face class as the important one. Therefore, they rarely implement blended learning in the classroom. Similarly, Yang (2012) found that some problems perceived by the teachers in implementing blended learning are the changing role of the teachers and students, small sense of community building, lack of training for blended learning and lack of knowledge about new system or technology. Moreover, learners in blended learning system are changed from passive learners to be active ones. They become researchers, practitioners, and collaborators because a dynamic and adoptive process of blended learning makes them interact with other learning subsystems, including instructor, institution, learning support, content, and technology (Wang et al., 2015).

Despite the many existing literatures of blended learning, very little attention has been geared to examining EFL teachers' professional experiences of blended learning implementation. Previous studies discussed earlier mainly focused on the actual enactment of such approach. Moreover, the use of narrative inquiry as a methodology in investigating the issue is rarely anchored. Therefore, the present study was designed to uncover three Indonesian EFL teachers' professional experiences of blended learning in schooling sectors to fill this gap.

\section{Method}

\section{Design}

The present study investigated lived experienced of EFL teachers in blended learning implementation. Since the nature of data were in the forms of storied experiences, narrative inquiry was employed. As a research design, narrative research focuses on studying single person and collecting data from an individual's experiences and stories (Creswell, 2012). The design also provides the possibility to understand how the personal and social aspects are intertwined in teachers' lives and how these experiences are shaped by the larger social and institutional narratives in which they live (Clandinin, 2006). In this study, the researchers engaged with the teachers' lived experiences and understood those experiences within the process of meaning-making. The participating teachers storied their experiences, perceptions, and challenges during blended learning enactment and how these affect their professionalism. 


\section{Participant Recruitment}

After sharing, discussing and continuing to intensive personal communication, the researcher concludes that the three teachers who applied blended learning were purposefully or intentionally selected as the participants to understand the blended learning.The study involved three EFL teachers in State Senior High School 2 Pamekasan who were given open-ended questionnaires and interviews to gain their views and practice about implementing blended learning. all of them are categorized as professional teacher like what stated in law of republic Indonesia number 14 year 2005 regarding teachers and lectures and has been teaching EFL more than 20 years.

Table 1. Participants' Profiles

\begin{tabular}{ccccc}
\hline No & $\begin{array}{c}\text { Participant } \\
\text { (pseudonym) }\end{array}$ & Gender & $\begin{array}{c}\text { Educational } \\
\text { Background }\end{array}$ & Teaching Experiences \\
\hline 1 & T1 & Male & Master degree & 32 years \\
2 & T2 & Female & Bachelor degree & 30 years \\
3 & T3 & Female & Bachelor degree & 21 years \\
\hline
\end{tabular}

\section{Data Collection and Analysis Procedures}

Data in this study were generated through semi-structured interview with the teachers concerning their professional experiences in the blended learning enactment during COVID-19 pandemic. To obtain access and data, at the first, the researcher came to school to have an interview related to the teachers' identity of their professional careers and their previous experiences in teaching English during pandemic. The researcher also explained the purpose of conducting this study and distributed narrative frame and narrative box. The second, the researcher met the teachers for the second time by interviewing the teachers to look for deeper information about the personal teacher experiences. It is related to the design, challenges and the strategies in implementing blended learning. It was done by recording their story. At the last, the researcher asked further information through WhatsApps when unclear information from the interview was found.

To analyze the data, the researchers conducted multiple reading of the interview transcript in order to achieve global understanding from the participants' stories. Afterward, the researchers identified emerging themes relevant to the framework of the study and narrative inquiry space which includes past, present, and future aspirations. Table 2 exemplifies the study's theme and coding approach in the data analysis.

Table 2. Coding procedure

\begin{tabular}{ll}
\hline & \multicolumn{1}{c}{ Teachers' Experience } \\
\hline Code & Meaning \\
T1 & Teacher 1 \\
T2 & Teacher 2 \\
T3 & Teacher 3 \\
Tep & Teaching English in Pandemic \\
Tepol & Teaching English in pandemic (online learning) \\
Prol & Problem in online leaning \\
Dbl & Design of Blended Learning \\
Sr & Students' Response \\
Ush & Unforgettable stories (Happy Experience) \\
Uss & Unforgettable stories (Sad Experience) \\
Usf & Unforgettable stories (Funny Experience) \\
Cp & Current Problem \\
Bio & Break it out \\
Ho & Hope \\
\hline
\end{tabular}




\section{Findings}

Findings in this study are detailed into seven themes: 1) Teaching English during COVID-19 pandemic, 2) Enacting blended learning in the class, 3) Listening to students' responses in blended learning, 4) Salient stories, 5) Hindrances in belnded learning enactment, and 6) Future aspirations.

\section{Teaching English duing COVID-19 Pandemic}

Online learning that was applied during the pandemic gives new stories for teachers in terms of teaching and learning. There are many new experiences in implementing full online learning such as finding material, preparing a suitable media for students, and designing learning activities. It is also challanging for the teachers to create interesting learning activities using technology so that the learning objective can be reached. In term of technology for learning process T1 narrates that:

\section{Excerpt 1}

I am able to know some technology or platform and how to use it, especially in the learning process. Before this pandemic occurred, we only used this technology to type some reports, chat, and communicate. But since the COVID-19 pandemic, we can better know the several online platforms that can be used for learning processes such as edmodo, Google classroom, zoom meeting, and even whatsapps can be used as an interactive learning media.

A similar narration from T2 and T3 were explained related to technology used. Even though the teachers felt confused about finding suitable platform for the students, the teachers try to various technology or platforms that can be applied in full online learning.

Excerpt 2

At the beginning, I applied media such as YouTube, video presentation and PowerPoint.

\section{Excerpt 3}

I start using such kind of online platform since online class. but i don't really know which one is suitable for my student. Therefore, at the beginning $i$ use youtube video to explain the material.

Moreover, teaching english as a second language for developed country in this pandemic situation are challenging. The implementation of full online learning raise some problems. Teachers found it hard in explaining the english skill. Another problems also come from the students where they have different motivation to learn. In addition, full online learning in this pandemic cannot run well.

\section{Excerpt 4}

I cannot explain the detail concept because of time allocation. Meanwhile. My students have limitation for the avaibility of internet balance. Teaching and learning English is conducted through conventional way so far. Students have less awarneess of independent learning.

Similarly, T2 and T3 recognized that the implementation of full online learning was hard to be implemented.

\section{Excerpt 5}

Ifound that my students present list is incomplete.

\section{Excerpt 6}

At the beginning of its implementation, online learning was not effective because my students do not understand my instruction when $i$ use full english. My students was passive in online class and it was hard for me to control them.

Under these themes, teachers' experience represented the situation that teaching English in pandemic situation using full online learning is challenging. It needs their professionalism to teach eventough in pandemic situation. It is clearly seen that the three teachers were pushed to teach english by implementing full online learning. At the beginning of pandemic, it was found that full online learning made the teachers use various online platforms suitable for the students' condition. In other hand, from the narratives, full online learning was seen difficult to be implemented because of some factors. 


\section{Enacting Blended Learning in the Class}

In July 2020, the government implemented the new normal concept, which means that there is a new life order in all aspects of life. In educational aspect, the government has begun to make regulations to allow the learning process to be carried out in schools for green zone. However, educational stakeholder must meet several requirements to be able to carry out learning at school. Therefore, learning using blended learning seems appropriate to be applied in this new normal era. In terms of blended learning, all the three teachers T1, T2, and T3 have the same response, this method is not something new for them. Teachers have attended training for $21^{\text {st }}$ century teachers related to blended learning, but teachers have not really understood the real design because they rarely and even have never implemented it.

\section{Excerpt 7}

Blended learning is combining conventional learning and online learning. It was not a new concept anymore; blended learning was expected that teachers are technology literate. I actually implemented it in 2012, if I couldn't teach to the class, I gave assignments to students via WhatsApp and e-mail. My students also have to submit assignments on WhatsApp / e-mail within a certain time limit.

eanwhile, T2 stated that blended learning is a mixed method, and T2 has been applying blended learning since the school began to implement face-to-face learning in new normal era during this pandemic.

\section{Excerpt 8}

Blended is a mixture of online and face to face learning, I have just implemented these kinds of learning in this pandemic, this is in line with the school policy.

T3 added that blended learning has been known for a long time, but the teaching and learning process in some school is more often applied using face-to-face

\section{Excerpt 9 \\ I had known the concept of blended learning before the pandemic. Blended learning is applied for long -distance learning. Blended learning has only been implemented in this school since July. This is in line with the government recommendations.}

For the application of bended learning and how to create a new learning system that is more suitable in the pandemic era, teachers are expected to continuously integrate conventional teaching and modern teaching. Here, the three teachers tell how they apply and integrate the blended learning model (online and offline). T1 use his online classes by presenting/explaining the material then it can be continued by giving reinforcement for the material in his face-to-face meetings. In contrast, $\mathrm{T} 1$ explains the material in a face-to-face meeting then giving assignments in his online learning or online class.

\section{Excerpt 10 \\ I explained the material in online class, and enrichment for face to face class. For example, when news item text that is conducted through online, I explain the material, the examples of text and their generic structures. Then at the next meeting in face-to-face class, I discuss the previous topic also I ask for responses or feedback from students. So, my students can understand more about the concept of the material that I convey.}

Furthermore, T2 stated that some preparations were made before the online meeting or online class. The day before or in the evening before the class, T2 shared a grid of material through the WhatsApp group and instructed students to learn. Therefore, during online classes, students can understand the material and answer some questions from the teacher. If the students find difficulties, T2 can respond 
or follow up in face-to-face meetings. It is also done by T3 where she shares the materials and reexplains the material in face-to-face class.

\section{Excerpt 11}

I share material before online meeting trough the WhatsApp group, next, for the students' difficulties or learning objectives which is not achieved yet can be discussed and resolved during face-to-face meetings.

\section{Excerpt 12}

I share videos/PPT/even text to students during online classes. Then at the faceto-face meeting, I explained again the material given during the online class. This way I can see my students whether they understand or don't understand.

In terms of time allocation between online and face to face classes, all the three teachers answered the same thing. It is because in its implementation, the schedule had been determined by the school. There is a reduction in time at each meeting during this pandemic andclass divisions. This is because the schools have to keep social distancing as the government expects. Therefore, the implementation of blended learning during this pandemic was carried out by reducing time allocation and dividing the number of students in each meeting.

\section{Excerpt 13}

Online per level, meaning that if class 10 is scheduled, all 10 graders will carry out online classes and it is divided into 2 shifts. For example, shift 1 class 7-10 and shift 2 10-1 class have arranged the schedule.

\section{Excerpt 14}

For the schedule, I follow the schedule from school

\section{Excerpt 15}

Schedule alternately. For example, today is grade 11, then the next day is grade 12. Class distribution is scheduled in 2 shifts.

The implementation of Blended learning or collaboration between face to face and online learning which is implemented in high schools during the COVID-19 pandemic received a good response from the three English teachers. Blended learning is considered better than full online learning although there are still some challenges in its implementation.

\section{Excerpt 16}

I think blended learning is more effective than full online learning. Full online learning cannot be applied to English learning. Collaboration between online and face to face can help teaching and learning process. Some questions and materials that require more explanation during online class can be developed and explained in a face-to-face class. To achieve the learning objective during pandemic, blended learning is the right method.

\section{Excerpt 17}

The combination between face-to-face and online learning is better. If the learning objectives are not achieved during online learning, I can continue through face-toface classes. In online learning, we can get to know several technologies that can help students in learning.

\section{Excerpt 18}

In online learning, most students were quiet and less active, but in face-to-face class, students are communicative and active. When I asked a question, they answer the question actively. For me, face-to-face classes can be used to provide 
feedback, and I can monitor my students' progress. I prefer blended learning for my class.

Furthermore, one of the factors that influence the success of the blended learning process is technology and learning platforms. The finding reveals that the three teachers have different learning management system (LMS). At the beginning of its implementation, they use different online platform that can be implemented to the students. But then, blended learning was decentralized using Google Classrooms, which the school regulates management, and WhatApps is for class groups.

Excerpt 19

At the beginning of online learning, I used Edmodo and Facebook for my students. But I think this platform is less effective for learning English. When I use meeting zoom, students complained about data packets running out so fast. Finally I used Goggle Classroom. It is connected to the principal's account to monitor the learning process both in offline and online learning.

\title{
Excerpt 20
}

I use Google Classroom; this school is centralized by the school for the use of Google Classroom.

\section{Excerpt 21}

I looked for the learning materials from YouTube, video, I made PPT and sent them to students. I took a photo of the worksheets, and then I sent them to students. I often asked about the condition of my students through WhatsApp group. Now I use WhatsApp and Google classroom because this application is used in this school.

In implementing blended learning, the students should have motivation to learn independently. Besides, the teachers play an important role in implementing the learning process using blended learning. It was found that the three teachers attended training to improve their skills.

\author{
Excerpt 22 \\ I attended webinar training to improve my ICT skills and I learned how to seek \\ information and concepts on how to implement the effective blended learning. \\ Fortunately, all teachers in this school get training in the application of blended \\ learning.
}

\section{Excerpt 23}

Apart from school, I participated in the English teacher training to increase the application of blended learning held by several universities in Indonesiaseveral universities in Indonesia.

\section{Excerpt 24}

Initially, I didn't understand the concept of blended learning, I used to call it daring and luring, but after I attended training from school and blended web mobile learning training organized by the educational department, I understood how to apply blended learning.

From the teachers' story, it was found that the school had trained and facilitated the teachers to conduct blended learning. After attending the training, they learned how to design lesson plans,s, assess, and create an effective teaching and learning process. Furthermore, Regarding to the effectiveness between full online and blended learning, the three teachers said that they prefer blended learning to full online learning for teaching and learning during the pandemic. 


\title{
Listening to Students' Responses in the Blended Learning
}

This part is a story from the teachers related to the students' responses during blended learning in pandemic situation. The story reveals that the T1 realized that the students are heterogens, it means that they have their own character in terms of learning. T1 found that the students are vary in learning during this pandemic, it depends on their motivation and creativities. In other hand, the students should be responsible and independent in learning. Meanwhile, T2 found that the students with low motivation in learning tend to be passive. The students' responses are explained by the teachers as follows:

\begin{abstract}
Excerpt 25
My students are heterogenic, my students who have high enthusiasm, motivation and learning creativity will look for additional references or materials to learn. In contrast, students with low learning enthusiasm will not try to find other learning sources and they are more passive in the teaching and learning process.
\end{abstract}

\section{Excerpt 26}

Some students who have low motivation tend not to take a part in online class. They attended for a while only filling attendance list. They also didn't want to take notes, they didn't watch the videos and PPT. I sent to them. They argue that they don't have any internet connection. They prefer to borrow books from friends to note materials rather than take part in the online learning process.

In addition, T3 also tells her story related to the students response. It was found that the students are passive for online class even though all the students attend the online class. Therefore, the teachers conduct such kind of reinforcement or follow up in face-to-face class.

Excerpt 27

in my online class, when $i$ asked them to read a text, they will answer "yes" but when $i$ asked some questions related to the text, they didn't anwer. So $i$ think my students do not read. my students are silents and passive in my online. They will be silent even though they have difficulties, they are attending the online class, it is proven by attendence list, but they are passive.

\section{Salient Stories}

The teacher is a role model for students in the teaching and learning process and in students' success in real life. A teacher who has been teaching for many years has already many experiences. They meet different changes in the curriculum, the heterogeneous character of students, and professional demands. During this pandemic, the learning system changed from conventional to online learning or a combination of the two learning models (blended learning).

Teachers of course have many experiences both joyful and sorrowful experiences, which are very impressed for teachers especially during this pandemic. T1 describes his experience in teaching English during this pandemic. As a teacher who has been teaching for 32 years, T1 has many experiences in teaching and learning, especially during a pandemic where this situation has never been experienced before (new experience).

\section{Excerpt 28}

I use meeting zoom, students complained about data packets running out so fast, it's around 1,5 GB. Another complains was from parents where they are also lack of financial because of the pandemic. Meanwhile, for happy experience, I realize that online learning in this pandemic is a blessing disguise. it is because my students and I can understand more about technology especially in educational context. The students' score for their assignment are better because they can find another reference from online source. 
Another story from T2 and T3 reveals that the implementation of blended learning in this pandemic brings unforgettable story for them. T2 explained that the students did not attend the class because of waking up late. The students also use the balance or internet balance given by the school for playing online game. Meanwhile, T3 told that her students are less active. Only 1 of 40 students is active in her online class. She continues that sometime an active student cannot attend her online class because of internet connection. It was her sad experience in implementing blended learning during this pandemic.

Excerpt 29

One day, when I was teaching and it ended at 9. My students filled attendance list at 11. When I asked, my students answered that it is because of overslept. I also often spend 25 minutes in my meeting just to advise and motivate my students. When they were attending online class from home and I found my student was sleeping, I found the data package for internet connection provided by the school was used to play online games.

Excerpt 30

During the learning process, I once found only 1 student out of 40 students who try to answer my questions. In addition, some students are out of the online class after filling out the attendance list. Students who are diligent and enthusiastic in learning sometimes cannot participate in learning process because of several factors such as no signal and running out of internet packages. I found my students have to go to other places just to attend English class virtually. when I give them assignment in online class, almost the students' answer is the same; it may be taken from the same sources.

\section{Hindrances during Blended Learning Enactment}

Based on the story, the teachers found some problems in implementing blended learning during pandemic. The problems mostly come up in online class; it relates to the facilities and students motivation. In addition, time allocation can be a problem for the students in implementing blended learning during pandemic. T1 told that the concept or the material cannot be explained in detail during online class because of time allocation, internet connection, students' motivation, schedule, and internet balance.

Excerpt 31

I cannot explain the detail concept because of time allocation. Meanwhile. My students look so confuse to cathec the English material. I found my students do not join the online class because they dont have any balance for the internet connection, besides students are heterogeneous in term of learning. They have different self-awareness to learn". Finally, not all the classes can be scheduled for online and face-to-face class because of the limitation of scheduling.

Meanwhile, T2 and T3 found that the problem also reveals in implementing blended learning during pandemic. It was in line with T1, it was hard to teach English as second language in pandemic. The English skill cannot be taught maximally. Other same problems also related to the internet connection and internet balance in her online class. Besides, students' motivation and scheduling is also including as a problem in implementing blended learning during pandemic.

Excerpt 32

when I teach grammar in online class for grade $x 1$, it was hard to teach direct and indirect because they have low capability in grammar. Besides, students' motivation is low my student rarely attend the online class because of internet connection or internet balance. 


\title{
Excerpt 33
}

My students loss of signal so that they can't attend the class on time. when I send material to the students, for example I share the video about English conversation, I cannot control weather the students watch the video or not.

I found my students are passive in online class, they will be silent if they have problem or they don't understand yet.

Related to the previous theme about problems in implementing blended learning such as students' balance availability, scheduling, how to integrate face-to-face and online learning, T1 explained that the government and school have given the solution by giving internet balance for the students. Furthermore, the government also shortened the time duration in the teaching and learning process during this pandemic and decreased the competence standard by not reaching the curriculum target, but it was only for learning experience.

\begin{abstract}
Excerpt 34
in this school each student was give internet balance. It was 20.000/month. the government also gave the internet balance for teacher and students 30GB/Month fortunately, in this pandemic, teaching and learning duration was shortening and its process is only for learning experience rather than reaching the curriculum target. I believe that blended learning can reach the curriculum target.
\end{abstract}

\section{Future Aspirations}

In this theme, the teachers narrate their evaluation and hope to the existing blended learning during pandemic situation. Teachers perceived that blended learning gave a new and different nuance to the EFL teaching, especially during pandemic situation. Based on the story, T1, T2 and T3 have been trying to better implement blended learning in pandemic situations. It means that the teachers try to find the best to teach English as a second language to the students using blended learning. T1 explains that blended learning is a suitable and effective method to be implemented in the school for pandemic situation. Face-to-face class can be used to give some enforcement or deeper explanation to the students when they have any problem in online class. Moreover, it can be used for feedback and real interaction to the students.

For the future, T1 is interested in implementing blended learning even though the pandemic ends. The use of ICT should be implemented in teaching and learning process. In addition, T1 will improve his self-evaluation to the blended learning implementation so that the future implementation will be better. Designing a suitable material, finding a suitable online platform will be his concern.

\section{Excerpt 36}

blended learning is good, it is more efficient. The use of ICT will be implemented even though the pandemic ends. ICT should be implemented to support education 4.0. Besides, the implementation of blended learning can be improved by designing an interesting material and the use of suitable platform to the students. For the next, it can reach the learning objective in the curriculum rather than learning experience like in this pandemic situation.

In addition, T2 and T3 have the same opinion that the implementation of blended learning in this pandemic situation is more effective than full online learning. They prefer implementing blended learning. They hope that the implementation of blended learning can be implemented even though the pandemic ends. T2 told that the school will implement credit system (sks) in the next semester. The use of blended learning can support that learning system; therefore, the school should have internal policy related to implementing blended learning at the school. In addition, T2 hope that the students' motivation will arise. The students' motivation also supports the implementation of blended learning, so she will motivate the students about the importance of ICT in learning. Meanwhile, T3 realized that the implementation of blended learning has its own challenge for the student especially in online class but it doesn't mean that blended learning cannot be implemented after the pandemic. T3 will be back to the face-to-face class but the use of ICT will be implemented as well. 


\begin{abstract}
Excerpt 37
I will use blended learning. I realized the important of ICT in learning. I will give such a kind of motivation to the students that learning is not enough conducted in a class, they can learn more outside trough technology. On next semester this school will implement credit system (SKS). Blended learning can support this system, and the school should have internal policy about its implementation.

Excerpt 38

My students are not ready yet for full online learning, so if the pandemic ends, I will be back to face-to-face and I will also use ICT to help students to learn more.
\end{abstract}

\title{
5. Discussion
}

The present study looked into EFL teachers' professional experiences in the blended learning enactment during COVID-19 pandemic. The findings showcase that the teaching and learning process at the beginning of the COVID-19 pandemic has been done from home through online learning platforms. In this case, teachers are required to be professional. Theoretically, teacher professionalism relates to teacher knowledge, teacher responsibility, and teacher autonomy (Jensvoll \& Lekang, 2018). Therefore, teachers have to be able to conduct teaching and learning process, transfer the knowledge to the students, conduct an evaluation so that the learning objective can be achieved in unprecedented situations. The participating teachers in the present study experienced multi-layered professionalism. In terms of teaching facility, it was found that the three EFL teachers tried to conduct an innovation in their teaching, such as using different online platforms (e.g., YouTube, Edmodo, Google classroom, Zoom meeting, and PowerPoint. Interestingly, all the three teachers voiced that the online teaching platforms were not effectively enacted due to poor Internet connection. Such a hindrance affects the teaching and learning process. In line with this finding, recent research by Watson (2020) documented that teachers' technological experiences is one of the challenges that determine the smoothness of instructional activities.

The findings of this study also reveal that the teachers much favor blended learning. This learning approach is considered better than full online learning although there are still some challenges in its implementation. It can be an alternative and effective strategy in the pandemic situation. Many language experts consider blended learning an ideal learning approach due to its accommodation of the strengths for face-to-face interaction and technology-based instruction (see Garrison \& Vaughan, 2008; Lalima \& Dangwal, 2017). Previous empirical studies by Arifani et al., 2019; and Kurucova et al., 2018) also support the positive values depicted in blended learning implementation. After the fieldwork, they argue that blended learning is more effective than the classical face-to-face or full online learning instruction. Another work by Wang et al. (2015) confirms that learners in blended learning approach are changed from passive to be active. Their findings shed light on the fact that the students worked collaboratively since a dynamic and adoptive process of blended learning facilitates them to interact with others through online learning systems.

Despite the salient and positive values depicted in blended learning enactment, the present study also captured multiple complexities encountered by the participating teachers. In our interview sessions, T1, T2 and T3 narrated that the problems mostly come up in online class including facilities, students self-regulated learning, and the schedule in implementing blended learning. In another study by Yang (2012), some problems perceived by the teachers in implementing blended learning are the changing role of the teachers and students, small sense of community building, lack of training for blended learning, and lack of technology knowledge. These complexities were noticed by the schools where the participating teachers work, such as inviting teachers to attend teacher professional workshops and providing ample Internet connection.

In terms of future aspiration, all the three teachers narrated that they try to find better strategies to implement blended learning in pandemic situation. In other words, the teachers try to find the best methods to teach English in the blended learning enactment. T1 and T2 contended that blended learning is good to implement for the future; T1 is interested in implementing blended learning even though the pandemic ends. The use of ICT should be implemented in teaching and learning process and give interesting learning experience for teacher and student, Therefore, blended learning may improve the effectiveness and efficiency of learning experiences meaningfully (Garrison \& Vaughan, 
2013: Twigg, 2003). Meanwhile, T2 narrated that the students' motivation also supports blended learning, so she will give more motivation to the students about the importance of ICT in learning. According to Kintu and Zhu (2017), factors to make successful blended learning are self-regulation, attitudes towards blended learning, family and social support, workload management, competences, gender and age.

\section{Conclusion}

This study attempted to document three EFL teachers' professional experiences in blended learning from narrative inquiry perspective. Findings suggest that all the educational activities or teaching and learning was conducted from home virtually and it was less successful and ineffective. Therefore, blended learning can be a catalyst for the learning activities in pandemic situation. Teacher professionalism is needed in implementing this blended learning. Therefore, teachers participated in several trainings on the application of blended learning, and even schools facilitated teachers in increasing their skills in ICT through training held by schools. Dealing with online platform, it was found that the teachers applied different online platforms to teach in online class such as Zoom, Edmodo, Google classroom and Whatsapps. The school centralized to use Google classroom as the main platform in online class. Furthermore, based on the teachers' lived experiences, it was found that the success of the implementation of blended learning in this pandemic is affected by some factors such as students' motivation, internet connection and scheduling at the school. In this study, Internet connection is a hindrance for the students in online learning; the students did not attend the class because of poor Internet connection. At last, the teachers are interested in continuing using blended learning for their EFL class and trying to find suitable materials for blended learning. Based on the present study's findings, it is recommended that the future researcher conduct a similar study in different levels of school and teachers. These differences will shed light on various perspectives, values, and beliefs depicted among the teachers in different levels of schooling.

\section{References}

Adedoyin, O. B., \& Soykan, E. (2020). COVID-19 pandemic and online learning: the challenges and opportunities. Interactive learning environments, 29 (3), 1-13. doi.org/ 10.1080/10494820.2020.1813180

Arifani, Y., Khaja, F., Suryanti, S., \& Wardhono, A. (2019). The influence of blended in-service teacher professional training on efl teacher creativity and teaching effectiveness. The Southeast Asian Journal of English Language Studies, 25(3), 126-136. doi.org/10.17576/3L2019-2503-10

Barkhuizen, G., \& Mendieta, J. (2019). Blended language learning in the Colombian context: a narrative inquiry of teacher ownership of curriculum change. Computer assisted language learning, 33(2), 1-21. doi.org/10.1080/09588221.2018.1553888

Barkhuizen, G., Benson, P., \& Chik, A. (2014). Narrative inquiry in language teaching and learning research. New York: Routledge

Bakalar, B. (2018). Book review: justice on both sides: transforming education through restorative justice. American Journal of Qualitative Research, 2(2), 145-149.

Clandinin, D. J. (2006). Narrative inquiry: A methodology for studying lived experience. Research Studies in Music Education, 27(1), 44-54. doi.org/10.1177/1321103X060270010301

Chan, E. Y. (2019). Blended learning dilemma: teacher education in the confucian heritage culture. Australian Journal of Teacher Education, 44(1),36-51. doi.org/10.14221/ajte.2018v44n1,3.

Creswell, J.W. (2012). Educational research: planning, conducting and evaluating quantitative and qualitative research.( 4th. Ed), Bostom, M.A : Pearson.

Connelly, F.M., \& Clandinin ,D.J. ( 2006). Narrative inquiry. In J.L. Green, G . Camilli \& P.B elmore (eds). Handbook of complementary methods in education research ( pp.477-488). Mahwa, New Jersey: Lawrence Erlbaum Associates, inc., publishers.

Dziuban, C., Graham, C., Moscal, P.D., Norberg, A., \& Sicilia, N. (2018). Blended learning: the new normal and emerging technologies. International Journal of Educational Technology in Higher Education, 15 (3), 1-16. doi.org/10.1186/s41239-017-0087-5 
Delone, W. H., \& McLean, E. R. (2003). The delone and mclean model of information systems success: a ten-year update. Journal of management information systems, 19(4), 9-30. doi.org/ 10.1080/07421222.2003.11045748

Garnham, C. \& Kaleta, R. (2002). Introduction to hybrid courses. Teaching with technology today, $8(6)$

Garrison, D. R., \& Vaughan, N. D. (2008). Blended learning in higher education. San Francisco: Jossey-Bass

Garrison, D. R., \& Vaughan, N. D. (2013). Blended learning in higher education, (1st ed.). San Francisco: Jossey-Bass Print.

Garrison, D. R., \& Kanuka, H. (2004). Blended learning: uncovering its transformative potential in higher education. Internet and Higher Education, 7(2), 95-105. doi.org/10.1016/j.iheduc.2004.02.001

Gillian, E., \& Lew, R. (2018). Incorporating research-based teaching techniques in E-learning to teach English articles. 3L: Language, Linguistics, Literature ${ }^{\circledR}, 24(1), 16-28$. doi.org/10.17576/3L-2018-2401-2

Jensvoll, M. H., \& Lekang, T. (2018). Strengthening professionalism through cooperative learning. Professional Development in Education, 44(4), 466-475. https://doi.org/10.1080/19415257.2017.1376223

Kintu, M. J., \& Zhu, C. (2016). Student characteristics and learning outcomes in a blended learning environment intervention in a Ugandan University. Electronic Journal of e-Learning, 14(3), 181-195.

Kintu, M.J, Zhu,C., \& Kagambe, E. (2017). Blended learning effectiveness: the relationship between student characteristics, design features and outcomes. International Journal of Educational Technology in Higher Education, 14(7), 1-20. doi.org/10.1186/s41239-017-00434

Kiilo, T., \& Kutsar, D. (2012). Exploring constructivist social learning practices in aiding Russianspeaking teachers to learn Estonian: an action research approach. Educational Action Research, 20(4), 587-604. doi.org/10.1080/09650792.2012.727649

Kurucova, Z., Medová, J., \& Tirpakova, A. (2018). The effect of different online education modes on the English language learning of media studies students. Cogent Education, 5(1), 1-13. doi.org/10.1080/2331186X.2018.1523514

Kocoglu, Z., Ozek, Y. \& Kesli, Y. (2011). Blended learning: Investigating its potential in an English language teacher training program. Australasian Journal of Educational Technology, 27(7), 1124-1134. doi.org/10.14742/ajet.908

Lie, A. (2020, May 2). COVID-19 disruption and the widening digital divide. The Jakarta Post https://www.the-jakartapost.com/academia/2020/05/02/COVID-19 -disruption-and-thewidening-digital-divide.html

Lalima \& Dangwal, K.L (2017). Blended learning: an innovative approach. Universal Journal of Educational Research 5(1): 129-136. doi.org/10.13189/ujer.2017.050116

Nissen, E., \& Tea, E. (2012). Going blended: new challenges for second generation L2 tutors. Computer Assisted Language Learning, 25(2), 145-163. doi.org/10.1080/09588221.2011.636052

Piccoli, G., Ahmad, R., \& Ives, B. (2001). Web-based virtual learning environments: a research framework and a preliminary assessment of effectiveness in basic IT skill training. MIS Quarterly, 25(4), 401-426. Doi :https://doi.org/10.2307/3250989

Richards, J. C., \& Schmidt, R. (2010). Longman: Dictionary of language teaching \& applied linguistics (4th Ed.). Pearson Education Limited

Setyaningsih, E. (2020). Face-to-face or online learning: Students' perspectives on blended learning in Indonesia. Journal of English Language Studies 5 (1),1-14.

Siaran pers. ( 2020,15 juni). Panduan penyelenggaraan pembelajaran pada tahun ajaran dan tahun akademik baru di masa COVID-19. Retrieved from https://bersamahadapikorona.kemdikbud.go.id/panduan-penyelenggaraan-pembelajaranpada-tahun-ajaran-dan-tahun-akademik-baru-di-masa-covid-19/

Sriwichai, C.(2020). Students' readiness and problems in learning English through blended learning environment. Asian Journal of Education and Training , 6(1).23-34. 
doi.org/10.20448/journal.522.2020.61.23.34

Twigg, C. A. (2003). Improving learning and reducing costs: New models for online learning. EDUCAUSE Review, 38(5), 29-38

Wright.M.B, (2017). Blended learning: Student perception of face-to-face and online EFL lessons. Indonesian Journal of Applied Linguistics, 7 (1), 64-71. doi.org/10.17509/ijal.v7i1.6859

Wang, Y., Han, X., \& Yang, J. (2015). Revisiting the blended learning literature: using a complex adaptive systems framework. Journal of Educational Technology \& Society, 18(2): 380-393

World Health Organization. (2021, February 20). Coronavirus disease (COVID-19) outbreak situation, retrieved from https://www.who.int/emergencies/diseases/novel-coronavirus2019.

Watson, E. (2020). Education: The potential impact of social media and hashtag ideology on the classroom. Research in Social Sciences and Technology, 5(2), 40-56. doi.org/10.46303/ressat.05.02.3

Yang, Y. (2012). Blended learning for college students with English reading difficulties. Computer Assisted Language Learning, 25(5), 393-410.

Doi:https://doi.org/10.1080/09588221.2011.597767 